\title{
Philosophy of Science and Political Inquiry- Notes on Dowding, Weber and Myrdal
}

\author{
Jan-Erik Lane* \\ UNIGE, Geneva, Switzerland \\ Email: janeklane@gmail.com
}

How to cite this paper: Lane, J.-E. (2018). Philosophy of Science and Political Inquiry-Notes on Dowding, Weber and Myrdal. Open Journal of Philosophy, 8, 262-276.

https://doi.org/10.4236/ojpp.2018.83019

Received: April 9, 2018

Accepted: May 22, 2018

Published: May 25, 2018

Copyright (c) 2018 by author and Scientific Research Publishing Inc. This work is licensed under the Creative Commons Attribution International License (CC BY 4.0).

http://creativecommons.org/licenses/by/4.0/

\begin{abstract}
Professor Dowding has written an interesting and stimulating book on the relevance (R) of general philosophical insights for the conduct of political science enquiry. In this paper, I challenge his positive analysis due to the relevance (R) difficulty. The social sciences have to struggle with a set of philosophical questions, but they hardly belong to general ontological or epistemological theories.
\end{abstract}

\section{Keywords}

Classical Issues in Philosophy, Fundamental Social and Political Science Problems, Dowding, Weber, Myrdal

\section{Introduction}

There has been a large debate about the study of politics, viz. can it be scientific? Politics, domestic and international, does not seems to fit very well with the tenets in standard textbooks on the scientific method and general philosophy of science.

The study of politics appears to be closer to the Geisteswissenshaften or Kulturwissenschaften in H. Rickert's $(1896,2012)$ famous distinctions between natural sciences and history and social sciences. One could argue that political science harbours a lot of enlightened journalism and little of theoretical or empirical generalization.

Keith Dowding has had the courage to discuss the nature of political science again from the general perspective of today's philosophy of science in The Philosophy and Methods of Political Science (Dowding, 2016). Drawing upon immense reading, Dowding makes a herculean effort to present key issues.

*Professor emeritus. 
The aim of my critique of Dowding (2016) is twofold. First, I believe that his approach is too much founded in general philosophy, which raises the problem of relevance ( $R$ ). For instance: Why would political science scholars and students want to know much about Saul Kripke and his analysis of the sentence "water = $\mathrm{H}_{2} \mathrm{O}$ "?

Second, I would argue that political science struggles all the time with a few central questions that belong to the philosophy of science in particular. They were identified by Maw Weber (1922), but Dowding does not even mention him. His book is too much focused upon topics in general Anglo-Saxon philosophy.

\section{PART I: DOWDING: Relevance®?}

The relevance problem (R) surfaces immediately in Chapter Two in Dowding (2016) on "isms". An overview is made of various fundamental doctrines about research and science in general, covering the entire history of philosophy of knowledge, besides a few specific isms in international relations. Here, there is a confusion of two different philosophical problems, namely the nature of universal concepts ("universals") on the one hand and the question of the reality of physical objects or events in time-space, realism versus phenomenology. Dowding claims: "Traditionally in philosophy, realism is opposed to nominalism,", having described "scientific realism"... as the "thesis that there is a world that exists independently of us." (Dowding, 2016: p. 14, 10). A realist like Quine is a hard core nominalist (Orenstein, 2014). His college Goodman was a nominalist and phenomenalist (Cohnitz, 2006). Armstrong (2009a, 2009b) is a realist about the external world as well as concerning the problem of universals, where many adhere simply to conceptualism: universals are abstractions from particulars. But why teach politics students these doctrines-the R question?

The R question must also be raised against the longish discussion in Chapter 3 on the analytic-synthetic distinction-so classical problem in centuries of philosophy. It became relevant again when Quine rejected Carnap's distinction, because in American pragmatist "meaning" as concepts do not exist-nominalism again. Thus, truth by analyticity can be scrapped. Dowding goes to great length at several places to describe Kripke's (1981) solution that bypasses Quine: the sentence "water $=\mathrm{H}_{2} \mathrm{O}$ " is a synthetic proposition that is true apriori. This equation links observable with unobservable in a lawlike generalisation, a natural law. But natural laws are not generally true apriori.

This renewal of Kantian language may be philosophically very important, but hardly for understanding politics. To me "water $=\mathrm{H}_{2} \mathrm{O}$ " is a proposition about a both necessary sufficient condition, whether true aposteriori (I think) or a priori. I have no difficulty with analyticity or meaning as concepts, lime many European philosophers. In political science, one must be extremely careful about the definitions of key terms, in order to avoid analyticity, or circular argument.

When exploring the nature of explanation, Dowding's Chapter 3's focus is again very much centered on the natural science debate, concerning the Hempel 
(1965) models. This is a huge debate in the philosophy of science, with a rather marginal input from the so-called cultural sciences. The $\mathrm{R}$ questions comes back when the criticism of Hempel's models are rendered account for. One recalls the counter-argument that history and the social sciences employ law like generalisations like physics, but they are just truisms.

One really lacks the alternative explanatory model— "the thing to do", as G.H. von Wright (1971) phrased it. It outlines an explanatory sketch that is much closer to what goes on in the social sciences, referring to intentionality and rationality. The Wright model appears to suit game theory very well, although not recognized. Reasons as the explanation are not much discussed, as one misses the distinction between the micro and macro that plays such a large role in the social sciences. Microscopic explanations could not possibly avoid intentions and reasons, whereas macroscopic explanation could speak of structures or culture.

The chapters 4 and 5 on theory and the testing of theories contain a lot of interesting information, but how about the $\mathrm{R}$ question? Take for instance the longish discussion of Kuhn's (1962) book on scientific revolutions in the natural sciences. What primarily would be of interest to the social science scholars and students is whether there occur paradigm shifts in political science and sociology for instance, so that we can speak of real revolutions also in these disciplines. There are candidates for Kuhn's concepts, not only in economics (Keynesianism, monetarism, etc.) but also in political science (rational choice-new institutionalism, realism-constructivism), but somehow we do not find Kuhn's language appropriate, perhaps because it really refers to the natural sciences.

Philosophy of science emerged as a sub discipline within theoretical philosophy after the Second World War with a distinct focus upon the growth of scientific knowledge. Do new theories advance our knowledge and if so, how? In the centre of attention was the concept of a scientific theory as well as how theories could be tested empirically so that we could speak advancement in our knowledge of the external world. Theory and observation was much discussed by scholars like Nagel, Hempel, Kuhn, Popper and Lakatos (Goodfrey-Smith, 2009; Cover, 2012), for instance. Theory versus observation soon turned out to be a very thorny problematic, with ramifications for verification and falsification of theories.

Dowding writes: "In this book, 'theory' is a general term that can stand for any of the following: ...conjecture framework, generalization, hypothesis, mechanism, methodology, model, organizing perspective, paradigm,..." (Dowding, 2016: p. 70).

This amounts to a much too wide definition or characterisation of a scientific theory. In standard textbooks in the philosophy of science, we often find the following definition:

DEF: A theory is a set of interrelated hypotheses in which figure prominently theoretical terms. 
Thus, the theory of consensus democracy would fall under this definition, but hardly a classification scheme or methodology for identifying various governments. Global warming would qualify as a theory but hardly a perspective like environmental skepticism.

The central components of a theory are:

- integration by deduction or a pattern of hypotheses

- a set of hypotheses with

- a few theoretical terms or concepts (Kaplan, 1964; Quine \& Ullian, 1978).

A single hypothesis like "Nietzsche suffered from megalomania when writing his auto-biography Ecce Homo" is not a theory, nor the hypothesis that "Illness affected Nietzsche's later books or booklets", although the syphilis hypothesis is discarded. It is true that Nietzsche presented a new morality, comprising a set of hypotheses, containing terms like personality, honour, valour and rejection of sin, pity and compassion.

Consider the most famous theory in the social science, Max Weber's theory of Protestantism and Capitalism. It comes in two versions (Weber, 2010, 1983):

- sufficient condition (Weber in 1904), historical approach:

- necessary condition (Weber in 1913), comparative approach.

The theory is full of hypotheses, centered on a distinction between two types of religious asceticism, and it comprises several theoretical terms-universalsand indirectly observables ones. Elegant and simple, considering the complexity of phenomena of civilisations. But is it true?

Weber's theory has aroused a huge literature, debating his concepts and the model of world religions and types of asceticism. Is it about Occidental rationality in general, not only the modern market economics and its new capitalist institutions?

Swedish economic historian Kurt Samuelson (1961) wrote an underestimated book on Weber's, questioning his correspondence or coherence with observable facts, or the phenomena. However elegant and encompassing the model may be, the derived implications must fit with the phenomena:

- Were all capitalists in Western Europe really Calvinists or Lutherans?

- Was there not capitalist trade on the Indian Ocean by Arab, Indian and Chinese merchants?

- Were not Chinese huge scale pottery factory capitalist enterprises, both public and private ones?

- Did not industrialization start early in Japan with the Meji restoration with roots in advanced handicraft under the Shugunate?

The most crucial question in the philosophy of science is to clarify the following: How to test theories by means of indicators on its universal concepts, or unobservables? Dowding devotes too little attention to this, which would be high on the $\mathrm{R}$ aspect. In the social sciences, we talk about manifest and latent variables: How are they related?

Dowding turns to the other extreme when introducing the concept of a model, equating it with the very demanding concept isomorphism. But this is mathe- 
matics and basic measurement theory: "Formally, an isomorphism is bijective morphism. Informally, an isomorphism is a map that preserves sets and relations among elements." Or to consult standard dictionaries:

1) Biology Similarity in form, as in organisms of different ancestry.

2) Mathematics A one-to-one correspondence between the elements of two sets such that the result of an operation on elements of one set corresponds to the result of the analogous operation on their images in the other set.

3) A close similarity in the crystalline structure of two or more substances of similar chemical composition. These definitions from standard dictionaries have no R.

A model in the social sciences is a) an equation or function on the one hand or b) a simplified conceptual picture comprising a few theoretical terms (Kaplan, 1964). Well-known modeling like in Rokkan's (1970) comparative work on Western Europe-cleavages, or Durkheim's model of social cohesion in primitive and industrial societies, have nothing to do with mathematical isomorph modeling.

On Kant: Dowding spends much time on Kant, but not his political theory that is appreciated more and more, focusing upon Rule of Law in its German version $=$ Rechtsstaat , both domestically and internationally (Kant, 1991).

Here, we have a quote on what he says about Kant: "Immanuel Kant distinguished categories of realism. Transcendental realists believe that the nature and existence of objects are wholly independent of us; the empirical realist believes that we can perceive the real objects and gain knowledge of them. Kant also believed that perception gives us knowledge only of appearances and not reality, so the empirical realist must also be a transcendental idealist-that is, material objects only consist in their appearances to us." (Dowding, 2016: pp. 14-15).

I fully agree with Bertrand Russell (2004) that Kant's epistemology-“das Ding an sich"-is fundamentally flawed. Here, the R-question comes with full force: Why teach political science students this? The point is not whether Dowding describes schools of epistemology and ontology correct (doubtfulwhy not indirect realism?), but that he insists on teaching a Kant that is largely irrelevant.

To take an example: Assume we observe the 1871 conference at Versailles, and focus upon Bismarck: What is appearance against "Ding an sich"? Colours, clothes, mustage versus atomic structure or molecules? The political scientist would concentrate upon Sayings and Hidden Intention: Did Bismarck already 1871 anticipate French "revanchismus" (Alsace-Lorraine) that would crush his newly created Empire?

In Chapter 6 (causality) and Chapter 7 (methods), there is much to learn for students, as the problem of relevance ${ }^{\oplus}$ is less acute. Causality is decomposed into correlation/regression plus counter-factual. Universal generalisations, A is B, are said to harbor necessity, but there is nothing necessary about the classical laws of nature. The paradox of counter-factuals is that they are always true, because the 
antecedent is false. I would agree with Hume that causation is a murky concept and not really so important in an age with probabilism, randomness, reversed causality and the chaos approaches.

Chapter 8 presents a profound analysis of the nature of concepts, but the $\mathrm{R}$-question returns. Dowding says that concepts should be primitives as much as possible, meaning undefined. Why? That is a requirement in axiomatization, which hardly ever takes place in political science or the social sciences. Moreover, concepts must be value-free or value neutral-Can they really be so? See Weber against Myrdal below!

Then he does not hesitate to bring up the problem of whether concepts "exist". This is perhaps the most debated issue in the history of philosophy-medieval philosophy e.g.- - besides the existence of an external world of some kind. What is the relevance ${ }^{\circledR}$ of the following statement: "Our conception of a minister thus generated will be theoretical. But we can consider that the concept exists...And it is doubtful there are any significant changes in empirical analysis if you prefer to take an anti-realist or instrumental stance... (Dowding, 2016: p. 202). So, why bring up this issue again from Chapter 2?

Terms offer concepts when they have connotation. They may also have denotation. Only denotation can be said to exist in space-time, as sets or values for variables. Muddled concepts have too many connotations or contrary ones, like 'social capital'. 'Social capital' also lacks an unambiguous measurement indicator for determining the denotation.

Finally, Dowding brings up "analytic political philosophy". We miss very much an overview of its themes like e.g.: n-person games, Condorcet winner, Arrow, Nurmi, the chaos theorem, etc. Instead, Dowding brings up his mentor, Brian Barry (1970), who wrote an excellent textbook on analytic political philosophy. Dowding, however, introduces his work in ethics, which is not philosophy of science due to the meta-ethical difficulty: What is truth in ethics?

Barry (1995) transformed Adam Smith's idea of the impartial observer (Theory of Moral Sentiments from 1759) into a full scale definition of justice as impartiality. Yet, impartiality is a necessary condition for legal justice, but not a sufficient condition for social justice. Consider a race in the Olympic games: Impartiality ex ante would be justice, but impartiality ex post would be incomprehensible. Justice is mutual agreement, as Hume taught. Or when a left government is elected, one may expect to pursue partial policies for the lower and middle classes.

In textbooks about the methodology of the social sciences, one finds a list of issues that bear upon the philosophy of science. I guess politics students would be more interested in these than in Kripke's new solution of the synthetic aposteriori problem, inherited from Kant. Here, we have for instance: the subjectivity-objectivity problematic.

The subjectivity-objectivity problematic is at the core of the social sciences and humanities, figuring most prominently in the post-modernist upheaval against analytical philosophy of science. It covers two very different themes: 
Subjectivity I. The subjective nature of social science, from the point of view of the humans: interior aspects, the mind, beliefs, values, etc.

Subjectivity II. The subjective mode of analysis, from the point of view of the author/scholar: value loaded concepts, biases, value premises, etc.

I will look at these two entirely different forms of subjectivity below.

\section{PART II. Subjectivity I (Weber)}

The conceptual scheme of means and ends for the analysis of action in a wide sense used to be considered a basic paradigm in the social sciences. Thus, Weber stated: "All serious reflection about the ultimate elements of meaningful human conduct is oriented primarily in terms of the categories "end" and "means." We desire something concretely either "for its own sake" or as a means of achieving something else which is more highly desired. The question of the appropriateness of the means for achieving a given end is undoubtedly accessible to scientific analysis. Inasmuch as we are able to determine (within the present limits of our knowledge) which means for the achievement of a proposed end are appropriate or inappropriate, we can in this way estimate the chances of attaining a certain end by certain available means." (Weber, 1949: pp. 52-53).

In the above quotation, Weber makes strong ontological and epistemological commitments: 1) Is human behavior intentional, i.e. involve means and ends? 2) What is the nature of an end or goal subjectively, and how can we know what ends drive a behavior? We have here a set of basic philosophical problems for the social and political sciences about behavior, action, goal-directed, motivation, intention, outcome.

Objectives or goals are subjective: If ends are simply the expression of preferences and if means and ends are difficult to separate, if ends are ambiguous and difficult to pin down, how can there be objective means-end analysis? If ends are subjective, can means-end analysis be scientifically objective? If the distinction between means and ends is a relative one, ends being in their turn means to further goals, and if ends are preferences, then how can the feasibility analysis of the means be value-neutral? People have ends and these are often means to further ends: the mean-end chains.

Teleological fallacy: The means accomplish the ends, we are told, but the outcomes follow the means, presumably, yet the end must guide the search for the means. Obviously, ends have to exist both $e x$ ante-before the policy is put into effect-as well as ex post-after the policy has been implemented-labyrinthine problems. Both ends cannot exist both before and after action.

The analysis of ends and means figure very prominently in the understanding of the motivation of behavior, as intentional action. Goals-ends or means-are more or less realistic, as they are based on beliefs and preferences. Imaginary goals often fail as unrealistic. Religious goals are figments of the imagination. Goals are subjective, guiding action through intentions. What were the goals of Bismarck when grabbing Alsace-Lorraine? Humiliation of France? Realistic as- 
sessment of stable conquest?

If means-end analysis appears troublesome in the enquiry into actions-past or present, then it is worth calling attention to its potential use in policy analysis, as it encompasses both value analysis and technology analysis. How are we to understand political technology in policy analysis? Political technology is the capacity of policymakers to accomplish goals by producing outputs in an environment; political technologies are the bases of policy-making, deriving the ends, searching out the means and finding the outcomes of political programs; economists approach public policy-making in a similar vein.

Teleology: ends as goals or means-ênd chain (desires, wishes, beliefs) - see Parsons, 1968. An analysis of the purpose and motive of an actor with these means-end concepts may be called "teleological analysis". The description of the units at the intentional level may be called "means-end context 1". Example: Napoleon believed that la grande armee was the instrument with which to realize his objective of subjugating Russia.

Causal analysis: Ends as real, results or outcomes. The other type of means-end sentence: $\mathrm{x}$ is in fact a means to a real end, is also common"means-end context 2". Here "end" refers to actual or objective states, "means" refers to actual or objective behaviors that are sufficient conditions for ends fulfillment, and $\mathrm{x}$ and $\mathrm{y}$ are not intentional objects. "Means-end relationship" denotes the actual causal relationship between real objective variables, $\mathrm{x}$ and $\mathrm{y}$. Example: Napoleon' imvsion of Russia 1812 became the cause of the start of his final defeat.

Sentences of this type may be used about performed means behaviors and of given end states-real outcomes - and of the relationship between these. On the other hand, this is a universal sentence and can then be formulated as follows: $\mathrm{X}$ is a means to end $\mathrm{Y}$ - "the paradigm-sentence of the policy sciences". Here $\mathrm{x}$ is called "means" only in the sense that an actor by performing $\mathrm{x}$ can bring about a real state y. An analysis in the policy sciences of the relationship between behavior $\mathrm{x}$ and state $\mathrm{y}$ with these means-end concepts may be called "causal analysis".

Weber attempts-stunningly - to show that means-end analysis is simply the same as causal analysis. Weber asserts: "Economic theory can tell us absolutely nothing more than that for the attainment of the given technical end $\mathrm{x}, \mathrm{v}$ is the sole appropriate means or is such together with yl and y2; that in the last analysis these and these differences in consequences and in rationality are associated with $\mathrm{y}, \mathrm{yl}$ and $\mathrm{y} 2$ respectively; and that their application and thus the attainment of the end $\mathrm{x}$ requires that the 'subsidiary consequences', $\mathrm{z} 1$ and $\mathrm{z} 2$ be taken into account. These are all merely reformulations of causal propositions, and to the extent that 'evaluations' can be imputed to them, they are exclusively of the type which is concerned with the degree of rationality of a prospective action." (Weber, 1949: p. 37).

A proposition $\mathrm{X}$ is a means to end $\mathrm{Y}$ states something about what is a means and an end in a policy; of course, it cannot be translated into $\mathrm{X}$ is the real cause 
of the real effect $Y$, because we cannot assume that the policy rests upon correct theory. There are policies that have beliefs about means and desired ends, but where the means will not cause the ends to be accomplished wrong beliefs! It is, of course, possible in policy analysis simply to state generally what in fact is a means-a real activity to an end as real outcome, but it not the reversal of cause and effect. Weber actually confuses teleological analysis-intention, motivation and other mind phenomena-with real causality in the external world.

Weber wrote a number of articles about the scientific status of the social and political sciences, gathered in his Gesammelte Aufsaetze zur Wissenschaftslehre (1922) about subjectivity II. The target of Weber's critique is the argument that social and political analysis cannot be value-neutral. If social analysis presupposes ends and if ends are inherently subjective phenomena, and if ends are only means to further ends, how can policy analysis be objective or value-neutral? Weber has two counter-arguments against the idea that means-end analysis is as mingled with values as the ends and means themselves.

Firstly, Weber tries to establish a distinction between the task of the scientist and the role of the citizen (Weber, 1949: p. 58). The argument that "the scientist qua scientist makes no value judgements" is based on a distinction between two types of analysis, theoretical analysis ("lays claim to validity as empirical truth") versus practical analysis ("validity of ethical norms"). Means-end analysis may be employed for various purposes; even if ends and means are subjective phenomena, then the analysis of these ends and means does not have to be subjective. It seems possible to make theoretical statements about ends and means, just as it appears to be possible to make practical statements about ends and means Weber clearly saw the possibility of a value-neutral description of end and means in policies ex ante their implementation.

Weber adhered to a non-cognitivist view on values.

\section{PART III: Subjectivty II (Myrdal)}

Gunnar Myrdak developed his methodological ideas in relation his empirical work in political economy and social economics, including a few large studies. He arrived late in life at conclusions much different from those he started from as a brilliant young scholar.

Myrdal's methodology—called "the theory of value premises"-was put forward for the first time in 1930 (Myrdal, 1930; Myrdal, 1933) and then formed an integral part of every work Myrdal published (Myrdal, 1944; Myrdal, 1957; Myrdal, 1968). Myrdal's vision in 1930 was “...the methodical and consistent application of a distinction in the philosophy of science" (Myrdal, 1930: p. 12). He writes: It is a question of drawing a completely clear line between 'what is' and 'what should be', between what can be affirmed to be true and what should be regarded as valuable (Myrdal, 1930: p. 11).

Myrdal states that one of the tasks of political economy is to describe actual facts and to analyse causal relationships, and another task is to analyse condi- 
tions and relationships within imagined social conditions, to consider means and ends. It is often possible to state something from a scientific point of view about the actually existing possibilities of realizing different political ends through certain means (Myrdal, 1930: p. 14). On the other hand it is not the task of political economy to try to prove ends or normative sentences; if political recommendations about ends and means are to be made on the basis of the results of scientific research, Myrdal continues, ....another premise is required which scientific research does not dispose of: a value sentence that decides what effects are politically desirable and what means are permissible (Myrdal, 1930: p. 14). It is obvious that Myrdal has in mind some form of practical syllogism, consisting of some theoretical premises, but where "...the conclusion is not scientific...” (p. 14). Starting from this philosophy of the social sciences Myrdal wanted to destroy "...social metaphysics, i.e. the method of rationalizing, of disguising politically normative sentences scientifically" (p. 13).

Two fundamental assumptions in the theory of value premises can now be specified: Scientific sentences consist of cognitive sentences, i.e. sentences (A1) which are either, true or false Cognitive sentences are different from normative sentences (A2). Myrdal started from a distinction between two kinds of propositions, those which are either true or false, and those which are neither true nor false, and which Myrdal calls "value sentences". To express this distinction Myrdal used-in 1930 as well as in later works-"theoretical" and "practical". For Myrdal the following identities hold true: theoretical or scientific sentence = cognitive sentence; practical sentence $=$ value sentence or normative sentence. For the theory of value premises the distinction between theoretical sentences and practical sentences has nothing to do with the distinction between theoretical terms and observational terms or theory versus observation (see e.g. Kaplan, 1964: pp. 54-62). Instead, the theory of value premises aims at a distinction expressed in other ways between "is-judgements" and "ought-judgements" or between "descriptive” and "prescriptive” language (see e.g. Ross, 1967).

Myrdal madein 1930 a sharp distinction between theoretical science and practical science: a theoretical science (scientific knowledge) is a science consisting only of theoretical sentences, and a practical science is a science including besides theoretical sentences at least some normative sentences. Another basic assumption is: Scientific knowledge can be objective, i.e. valid for all times, people (A3) and situations By distinguishing between cognitive and normative elements in the construction of concepts and propositions Myrdal wanted not only to clarify the cognitive status of scientific knowledge (theoretical science). Conversely, the application of this basic distinction in the philosophy of science would reveal the epistemological conditions of a practical science; as Myrdal expressed it in 1930, it would render an economic technology possible (Myrdal, 1930: p. 281).

According to Myrdal such practical knowledge cannot be based on normative arguments about general social principles stated in the name of science. Such an approach would obliterate the distinction between theoretical and practical 
science. The foundation of a practical political economy is "...that definite, concretized value premises should be-stated" (p. 285). Myrdal thought it possible to deduce policy solutions in a practical syllogism with the aid of normative sentences along with scientific sentences. The validity of a practical science depends not only on the truth of the cognitive sentences entering into it. The normative conclusions of a practical science cannot be derived from theoretical sentences alone, but require normative sentences as premises. And as the theory of value premises emphasizes, the practical argument is elliptic, if the normative sentences necessary for the derivation in a practical science are omitted. These value premises are statements expressing ends. How then are these value premises to be specified? Myrdal answers: In order that this relativized social policy may be practical in a proper sense, the only prerequisite is that the value premises mentioned are selected in such a way and so comprehensively that they correspond to the somewhat differing interests of strong social groups (Myrdal, 1930: p. 285).

A fourth basic assumption in the theory can be established here: Value premises are those normative sentences that express the values corresponding to the interests of strong social groups (A4). Two problems arise with regard to (A4). Why should only normative sentences that fulfil the restriction be value premises? The argument "practical in a proper sense" is precisely an expression devoid of content such as Myrdal wants to do away with. Secondly, how is this correspondence-provided that it is possible to make clear what it implies-to be established? The central idea is that, with the aid of the modern methods used in social psychology, economic technology... is built up on the views these people with their general attitude to social problems would hold, if they observed reality more correctly... (Myrdal, 1930: p. 289).

In the argument about economic technology a fifth assumption is inherent which can be formulated in the following way: If a science has relevance for practical issues, practical sentences or normative sentences must enter into this science, making it a practical science (AS) In 1930 Myrdal started from certain philosophical principles usually connected with the Uppsala school of philosophers as well as Max Weber, and of course from certain basic distinctions in the theory formation of political economy (Myrdal, 1930: Chap. 1). The assumptions (A1), (A2) and (A3) may be called "epistemological objectivism".

Myrdal's article from 1933 was an important addition to the methodology of 1930 (Myrdal, 1958: pp. 206-230). Value premises are now said to be relevant also for theoretical science, not only for an economic technology. Myrdal now argued that ends are not the only expression of value premises but also the means recommended are determined by value premises; in traditional policy analysis it was assumed according to Myrdal that: The basic idea of this principle in this: By splitting economic processes into 1) a given initial situation, 2) alternative means, and 3) the hypothetical end, it should be possible to concentrate all value judgements on the third link, viz., the purpose. However, the 
means-end analysis cannot be value-neutral: Now it is quite obvious that values are attached not only to "ends" but also to "means". Means are not ethically neutral. The value judgement must compare and choose between alternative courses. Value judgements thus refer always to whole sequences, not merely to the anticipated final outcome (Myrdal, 1958: pp. 210-211).

Thus, value premises have to be included in the means-end schema; Myrdal argued that "a priori ideas" are essential as principles of selection and that such ideas are in the last analysis “....an expression of a valuation which lends 'interest' to certain hypotheses and certain relations between facts" (p. 228). Myrdal supplemented his theory of value premises as the basis of practical syllogisms with a description of conditions that must be satisfied so that theoretical knowledge may emerge: Scientific knowledge is causally dependent on values (A6) However, this assumption has no logical relevance whatsoever for the distinction between is- and ought-sentences and thus between theoretical and practical science, but it reorients the methodology of 1930 towards the sociology of knowledge. "Value premise" refers not only to a type of normative sentence, but also more generally to values or valuations as distinct entities.

In an appendix to An American Dilemma (1944) entitled "Facts and Valuations” (Myrdal, 1958: pp. 119-164) Myrdal discusses methodological problems. The theory of value premises is rendered more complete in two respects. Firstly, the theory is expanded by the identification of criteria of value premises: explicitly stated, specific and concrete, relevant to the ideals of important social groups, realistic, consistent (pp. 157-158). Secondly, a new basic assumption is formulated: The value-loaded terms have a meaning and represent a theoretical approach, because the theoretical approach itself is determined by the valuations inherent in the governing ethos of a society (Myrdal, 1958: p. 163). This assumption can be formulated as follows: Scientific knowledge is determined by valuations (A7) (A7) is unclear as the sentence can stand for two different propositions. It could be (A6), but it could also refer to a different assumption: Scientific knowledge (theoretical science) is logically dependent on values (A8). In his next work Myrdal specified which of the interpretations should enter into the theory of value premises. Here (A7) is repeated: On the contrary, every study of a social problem, however limited in scope, is and must be determined by valuations (Myrdal, 1970: p. 55). But-and this is the essential thing-it is made quite clear that it stands for (A8).

In 1930 Myrdal was of the opinion that the validity of practical conclusions depends on the value premises that have to be made explicit in order that the syllogism is not to be elliptic. In 1970 Myrdal asserted that data should be established "...by theoretical analyses with the use of the same value premises..." (p. 56). Furthermore, he makes the demand that: (we)... determine approach and define concepts in terms of a set of value premises which have been explicitly stated (Myrdal, 1970: p. 5, my insertion). The position of 1970 implies that the validity of cognitive or theoretical sentences also depends on values, for logical reasons. Myrdal's conclusion in Objectivity in Social Research may be stated 
thus: Scientific knowledge is subjective, i.e. valid only for certain times, (A9) people and situations (for certain values) The assumption (A9) may be called "epistemological subjectivism". Myrdal's methodology, the so-called "theory of value premises", has now been analysed into a set of assumptions (A1)-(A9).

Below I will put forward a number of arguments by which I want to show that there are various flaws in the conjunction (A1)-(A9). The argument of contradiction: (A9) and (A3) are contradictory. The theory of value premises cannot contain both assumptions and at the same time be consistent. Nor is (A8) compatible with (A1) and (A2). If (A2) holds good, it cannot be true that valuations permeate cognitive sentences by logical necessity-as Myrdal writes. It is possible that there are causal relationships between valuations and cognitive sentences-i.e. what (A6) states. But this is not stated in (A8). The theory of value premises develops in the direction of epistemological subjectivism. According to Myrdal 1970 the results of theoretical research cannot be merely valid-as in 1930 - but must be valid relative to certain values.

The argument of non-sequitur: The following consideration forms the basis of (A5): But, of course, political economy must be practical. Also on that point there is full unanimity. The problem is only how it is to be done (Myrdal, 1930: p. 276). (A1) and (A2) are the starting-point and Myrdal distinguishes clearly between theoretical sentences (cognitive sentences) and practical sentences (normative sentences). Myrdal asserts consistently that in order to be practical a science must contain practical sentences. The next task is then to specify exactly how these value sentences are to be selected and combined with cognitive sentences. But-and this is the objection-why "must political economy be practical"?

Myrdal answers: Political economy has always aimed at being socio-political (Myrdal, 1930: p. 285). However, it does not follow that political economy-or any social science whatsoever-must be practical, i.e. contain normative sentences. It is quite feasible to establish different alternatives in a socio-political issue along various dimensions without simultaneously putting forward sentences about which alternative is to be preferred to others for ethical reasons. When (A5) falls, the construction of value premises and their selection, (A4), is superfluous for any relevance policy analysis may have for social problems. (c) The argument of reductio ad adsurdum: The theory of value premises asserts that Scientific knowledge is subjective (A9) The sentence "Scientific knowledge is subjective" enters into scientific knowledge. What is then the status of the sentence (A9) with regard to objective-subjective? We have: (A9) is subjective if (A9) is objective. (A9) thus implies a contradiction.

The combination of (A4) and (A8) results in an absurdity. On the one hand the theory of value premises contains the requirement: 1 )... to raise the valuations actually determining our theoretical as well as practical research to full awareness (Myrdal, 1970: p. 5). 352 On the other it asserts that the value premises should not be chosen arbitrarily. They must be founded on people's actual valuations (Myrdal, 1970: p. 65). In whatever way the argument about so-called 
"actual" values is specified, this requirement-i.e. 2)-involves the empirical description and establishment of values. This can only be done in theoretical science. A starting-point for the former requirement-1) - is that the distinction between theoretical and practical research can be maintained-even though Myrdal does not explain how.

The conjunction of 1) and 2) then produces the following argument: 1) If theoretical research, then values in theoretical research 2) If values in theoretical research, then they should be transformed into value premises 3) If value premises, then knowledge of actual values 4) If knowledge of actual values, then theoretical research 5) If theoretical research (on actual values), then values in theoretical research and so on. It is impossible to maintain at the same time that knowledge of values (valuations) is a necessary condition for theoretical research and that theoretical research is a necessary condition for knowledge of values (valuations).

Theories cannot be valid only in relation to certain value premises, logically.

\section{Conclusion}

Dowding writes about the philosophy of science from a most general philosophical approach, which results in the relevance $R$ question. The methodological positions of each Weber and Myrdal claims that the social sciences must have a different conduct of inquiry due to the subjectivity-objectivity difficulty-the great role that subjectivity, or mind phenomena plays in these disciplines as well as the value ingrained nature of social and political enquiry. The separation between epistemological subjectivism (II) and ontological subjectivism (I) is also relevant for the critique of post-modernist philosophy.

Subjectivism I is worth more research in order to clarify the role of mind phenomena in explanation in the social sciences.

\section{References}

Armstrong, D. (2009a). Scientific Realism and Nominalism. Cambridge: CUP.

Armstrong, D. (2009b). A Theory pf Universals. Cambridge: CUP.

Barry, B. (1970). Sociologists, Economists and Democracy. New York: Collier Macmillan. Barry, B. (1995). Justice as Impartiality. Oxford: OUP.

Cohnitz, D. (2006). Nelson Goodman. London: Routledge.

Cover, J. A. (2012). Philosophy of Science: The Central Issues. New York: Norton.

Dowding, K. (2016). The Philosophy and Methods of Political Science. London: Palgrave.

Goodfrey-Smith, P. (2009). Theory and Reality. Chicago, IL: Chicago U.P.

Hempel, C. (1965). Aspects of Scientific Explanation. New York: Free Press.

Kant, I. (1991). Political Writings. Cambridge: Cambridg U.P.

Kaplan, A. (1964). The Conduct of Inquiry. San Francisco, CA: Chandler.

Kripke, S. (1981). Naming and Necessity. Oxford: Wiley-Blackwell.

Kuhn, T. (1962). The Structure of Scientific Revolutions. Chicago, IL: Chicago U.P. 
Myrdal, G. (1930). Vetenskap och politik i nationalekonomien. Stockholm: Norstedt \& Soner. [English translation and revision: The Political Element in the Development of Economic Theory. London: Routledge \& Kegan Paul, 1953.]

Myrdal, G. (1933). Ends and Means in Political Economy. Zeitschrift fur National Okonomie, $I V$, 206-230. (Reprinted in Myrdal, 1958)

Myrdal, G. (1944). An American Dilemma. New York: Harper \& Row.

Myrdal, G. (1957). Economic Theory and Underdeveloped Regions. London: Gerald Duckworth.

Myrdal, G. (1958). Value in Social Theory. A Selection of Essays on Methodology. London: Routledge \& Kegan Paul.

Myrdal, G. (1968). An Asian Drama. An Inquiry into the Poverty of Nations. New York: Twentieth Century Fund and Pantheon Books.

Myrdal, G. (1970). Objectivity in Social Research. London: Gerald Duckworth.

Orenstein, A. (2014). W.V.O. Quine. London: Routledge.

Parsons, T. (1968). The Structure of Social Action. New York: Free Press.

Quine, W. v. O., \& Ullian, J. S. (1978). The Web of Belief. New York: Random House.

Rickert, H. (1896, 2012). Die Grenzen Der Naturwissenschaftlichen Begriffsbilding; Eine Logische Einleitung in Die Historischen Wissenschaften. Rarebooksclub.com.

Rokkan, S. (1970). Citizens Elections Parties. Approaches to the Comparative Study of the Processes of Development. Oslo: Universitetsforlaget.

Ross, A. (1967). Directives and Norms. New York: Humanities Press.

Russell, B. (2004). A History of Western Philosophy. London: Routledge.

Samuelsson, K. (1961). Religion and Economic Action: A Critique of Max Weber. New York: Harper.

von Wright, G. H. (1971) Explanation and Understanding. Ithaca: Cornell U.

Weber, M. (1949). The Methodology of the Social Sciences. New York: The Free Press.

Weber, M. (1922). Gesammelte Aufsiaeze zur Wissenschaftslehre. T'uebingen: J.C. Mohr.

Weber, M. (1983). The Sociology of Religion. Boston, MA: Beacon Press.

Weber, M. (2010). The Protestant Ethic and the Spirit of Capitalism. Oxford: OUP. 